\title{
Folklore, Animal Self-Medication, and Phytotherapy-Something Old, Something New, Something Borrowed, Some Things True
}

Author

Michael A. Huffman ${ }^{(D)}$

Affiliation

Primate Research Institute, Kyoto University, Inuyama, Japan

Key words

phytotherapy, traditional medicine, animal behavior, folklore, traditional ecological knowledge, zoopharmacognosy

received

accepted after revision

published online

March 5, 2021

July 30, 2021

October 8, 2021

Bibliography

Planta Med 2022; 88: 187-199

DOI 10.1055/a-1586-1665

ISSN 0032-0943

(C) 2021. Thieme. All rights reserved.

Georg Thieme Verlag KG, Rüdigerstraße 14,

70469 Stuttgart, Germany

Correspondence

Associate Professor Michael A. Huffman

Primate Research Institute, Kyoto University

41-2 Kanrin, 484-8506 Inuyama, Aichi, Japan

Phone: + 81 (0) 568630567 , Fax: + 81 (0) 568630085

huffman.michael.8n@kyoto-u.jp

\section{ABSTRACT}

The use of medicines was long considered by Western schools of thought to be a domain unique to humans; however, folklore/Traditional Ecological Knowledge (TEK) from around the world suggests that animals have also long provided inspiration for the discovery of some medicinal plants used to treat humans and their livestock. Searching for medicinal knowledge from animals depends on the recognition of their ability to select and effectively use medicinal plants to prevent or actively ameliorate disease and other homeostatic imbalances. The interdisciplinary field of animal self-medication is providing scientific evidence for this ability in species across the animal kingdom and lends support to animal-origin medicinal plant folklore and recent ethnomedicinal information. Here, 14 case studies of purported animal-inspired plant medicines used by cultures around the world are presented together with ethnomedicinal and pharmacological evidence. Based on this evidence, the diversity and potential mode of selfmedicative behaviors are considered. Over 20 animal species, including llama, sloth and jaguar in South America, reindeer and yak in Eurasia, langur and macaque in Asia, and chimpanzee, wild boar, porcupine and elephant in Africa, are linked to these case studies, representing a variety of potential preventative or therapeutic self-medicative behaviors. These examples provide an important perspective on what is likely to have been a much wider practice in the development of human traditional medicine. A role for animal self-medication research in the rejuvenation of old therapies and possible new discoveries of phytotherapies for human and livestock health is encouraged.

\section{Introduction}

The propensity of our hominin ancestors to use medicinal plants was pronounced and dates at least as far back as 50000 years. At the El Sidrón cave site in northern Spain, Homo (sapiens) neanderthalensis, an extinct species of archaic humans, ingested the nonnutritional medicinal plants Achillea millefolium (yarrow) and Matricaria chamomilla (chamomile) and the fungus Penicillium rubens, the source of penicillin [1], as shown by analysis of ingested particles trapped in the dental calculus of their fossilized teeth. All of these medicines are still in use today. The archaeological record of multiple sites across the Near East spanning the Lower Paleolithic to the Neolithic period suggests that the deliberate and continued use of medicinal plants was universal among Paleolithic hominins [2].

Two of the oldest written medicinal traditions, Ayurveda and Traditional Chinese Medicine (TMC), date back over 5000 years. Much of the world is still dependent upon the use of herbal medicines from these and other traditions for daily health needs. These treatments, found to be consistently effective, have become widely accepted as complementary health care treatments even in industrialized nations [3-7]. The interdisciplinary fields of ethnomedicine, ethnoveterinary medicine and ethnopharmacology investigate these and other long-standing written and oral 
traditions of medicinal plant use, and are sought after as sources of alternative treatments for human and livestock diseases in the face of growing antibiotic and antiviral resistance to synthetic drugs $[6,8-13]$.

It is reasonable to assume that knowledge of what plants are medicinal and for what purposes is acquired by humans as a result of regional independent discovery, the sharing of information between groups, and at the beginning, perhaps even between different hominin species that were intermixing at the time. One other possible route much less seriously considered until recently is the acquisition of medicinal plant use from the observation of wild animals. Cindy Engel reviewed this topic in great depth in her book Wild Health, mentioning over 320 animal species and 137 plant species [14]. Indigenous societies around the world have long credited the observation of animals to the discovery of some medicinal plants too $[9,15]$.

For example, according to the beliefs of the Blackfoot, an indigenous North American people of Montana (USA) and Alberta (Canada), Na'pi, their mythological creator, is believed to have taught humans to seek wisdom and advice from watching animals [16]. Today, and in the recent past, traditional healers among the WaTongwe in western Tanzania have discovered solutions to health problems from observing wild animals use plants when showing signs of sickness. These observations of elephant, bush pig, porcupine, and chimpanzee led them to the discovery of medicinal plants to treat such things as urinary infections, cholera, stomach upset, and diarrhea [17]. Innovative use of one of these plants has led to a treatment for sexually transmitted diseases and secondary infections in immunocompromised HIV patients in areas where access to modern antibiotics was limited and costly [17].

The pervasiveness of the animal origins of medicinal plant use in the literature raises the question of whether nonhuman animals played a larger role in the discovery of traditional medicines than once thought, and is there still more to learn? It has been argued that such 'folklore' is a metaphor for indigenous interpretations of actual social and ecological phenomena observed in nature [18]. The label of 'folklore' should not put us off. If there is reason to believe there is something to it, it deserves to be investigated more closely. People around the world traditionally living close to and dependent upon nature have an intimate knowledge of the ecology of their surroundings, simply because their survival depends on it. This body of knowledge perhaps is best viewed as Traditional Ecological Knowledge (TEK), defined as 'the sum of data and ideas acquired by a human group of its environment resulting from the group's use and occupation of a specific region over many generations' [19]. TEK includes the behavior of wild or domesticated animals of particular importance in their daily lives.

The ability of animals to self-medicate has now gained wide recognition among scientists, but it did not go unnoticed by a few early scholars such as Aristotle in 'Historia animalium' (384322 B. C.) and Pliny the Elder (ca. 77-79 CE) in 'Naturalis historia'. Both made several mentions of self-medicative-like behaviors in their descriptions of animal habits [20]. Given the universal adaptive value of such behavior, it should not be surprising that evidence is now available from a wide range of species from insects to mammals [21-27]. The scientific field of study into this is known as zoopharmacognosy or animal self-medication [21,28]. In simple terms, zoopharmacogosy focuses on understanding what impacts the health of animals, what they do to protect themselves from infection and, when sick, how they maintain physiological homeostasis [17, 22, 29-31]. Self-medicative behavior is currently divided into five basic modes: (1) 'sick behaviors' (lethargy, depression, anorexia, behavioral fever, basking behavior); (2) behavioral avoidance or reduction of the possibility for disease transmission (avoidance of feces-contaminated food, water, substrates); (3) dietary selection of items with a preventative or health maintenance effect (bioactive items eaten in small amounts or on a limited basis); (4) ingestion of a non-nutritional substance for the therapeutic treatment of a disease or its symptoms (use of toxic or biologically active items at low frequency or in small amounts; and (5) application of a substance to the body or a living space for the treatment or control of vectors or external health conditions (fur rubbing, anting, den/nest fumigation) [31]. These modes are used to evaluate the diversity and level of selfmedicative effort in the animal kingdom.

The first clear-cut demonstration of self-medication came from research on chimpanzees in western Tanzania. By the intentional ingestion of the extremely bitter juice extracted from the pith of Vernonia amygdalina Del (Asteraceae), chimpanzees suppress strongyle nematode infection and its associated symptoms when sick, bringing about relief of symptoms and a marked decrease in parasite load [21]. Interestingly, chimpanzees use the pith, and the WaTongwe, traditionally living in the same habitat, use the leaves to treat similar symptoms. It was demonstrated that they ingest approximately the same dose of the same major bioactive compound, and both chimpanzees and humans show signs of recovery within 20 hours [32-34]. However, given the widespread use of $V$. amygdalina across Sub-Saharan Africa by humans, even in areas where chimpanzees are not found, it is likely they discovered the plant's curative properties independently.

Pharmacological studies have demonstrated a wide array of biologically active properties in V. amygdalina $[35,36]$. The compounds have demonstrated anthelmintic (Oesophagostomum, Toxicara, Ancylostoma, Schistosoma, Entamoeba), antimalarial (P. falciparum) and tumor-growth-inhibition properties [33,37, 38]. This species also has many uses for the treatment of both human and livestock diseases [39, 40].

From the field and laboratory research on chimpanzee bitterpith chewing, a four-point criterion for demonstrating therapeutic self-medication was established and has become the standard for self-medication research: (1) identify the disease or symptom(s) being treated; (2) distinguish the use of a therapeutic agent from that of everyday food items; (3) demonstrate a positive change in health condition following self-medicative behavior; and (4) provide evidence for pharmacological activity from compounds present in the plant part ingested [21].

The study of animal self-medication provides an ecological and biological context for evaluating the animal origin folklore and TEK of some well-known traditional medicines and can help us to potentially derive different uses for them [41-45]. The study of chimpanzee bitter-pith chewing (which is a Mode 4 behavior) has already led to the discovery of 11 bioactive constituents in a new group called the steroid glucosides [37]. 
The goal of this paper is to present and evaluate a subset of such animal-origin medicinal plant use stories and recent ethnomedicinal literature based on the above mentioned four-point criterion. The potential level of medicinal activity in the plant assessed from the literature will be presented, and the most likely self-medicative mode of action the behavior could represent will be tentatively assigned. This is not intended to be an extensive review of the animal-origin medicinal plant use literature, nor is it intended to promote the plants described here for use as therapies. These examples will be discussed from the perspective of past and present roles for animal self-medication research in the evaluation and implementation of traditional medicines as potential phytotherapies in human and veterinary healthcare.

\section{Results and Discussion}

\section{Aeschynomene cristata Vatke var. cristata (Fabaceae): porcupine}

The origin of this species' use of this plant for medicinal purposes among the WaTongwe is linked to the observations of an African crested porcupine (Hystrix africaeaustralis, $\mathrm{H}$. cristata) by traditional healer Babu Kalunde of Tanzania. He observed the porcupine digging up and chewing on the roots of this plant. The porcupine passed blood in its stools from ingesting the plant's bitter roots. Kalunde closely monitored the outcome until the porcupine recovered from all symptoms a few days later $[17,46]$.

Kalunde was surprised that the porcupine would ingest the poisonous roots of the plant known to the WaTongwe as 'mulengelele', and not only survived but recovered from its illness. Kalunde next needed to convince members of his village suffering from similar symptoms to allow themselves to be treated. He did so by taking a measured dose himself to show that it was not toxic when taken in the appropriate dose. His grandson, my collaborator Mohamedi Seif Kalunde, later used mulengelele frequently to successfully treat patients coming to him with what he diagnosed as a sexually transmitted disease, possibly gonorrhea. The use of mulengelele became widespread among other WaTongwe healers for its overall antibiotic activity. With limited access to western HIV medications, mulengelele root extract was subsequently used to treat secondary symptoms of AIDS patients $[17,46]$.

Though pharmacological investigations have yet to be conducted, the effectiveness of the plant for treating sexually transmitted disease and dysentery-like symptoms of people in Kalunde's village all suggest antibiotic properties of A. cristata. On a visit to the Kew Gardens Herbarium in 1994, I came across a voucher specimen of $A$. cristata collected by the "University of Oxford Tanganyika Expedition" from the Mahale Mountains in 1959. On the label it reads 'antibiotic.' I assume that this is what the collector was told at Mahale by whoever guided them to the plant, although I am unable to verify this.

Based on the available information, this behavior can be classified tentatively as Mode 4 therapeutic self-medication by the porcupine.

\section{Amanita muscaria (L.) Lam. (Amanitaceae): caribou, reindeer, bear}

According to the Sámi reindeer herders of Finland, this mushroom, nutritious for humans when detoxified, is said to intoxicate reindeer when ingested. The animals are said to run about aimlessly, emitting atypical noises, and twitching their heads. Wild caribou, as reindeer are called in Canada, are reportedly affected in the same way [14]. The Khanty people of Western Siberia believed that bears eat these mushrooms for 'courage' during the mating season [47]. Based on these observations, the Khanty are reported to have ingested the mushrooms for their hallucinogenic properties to communicate with the spirit world and to meet powerful spirits with 'courage' [47].

A. muscaria was used as a hallucinogen in group rituals, as well as by the Chukchi, Koryak, Inuit, and Russians east of the Kolyma River and on the Kamchatka Peninsula [47]. The indigenous reindeer herders in Siberia and the Sámi herders also collected and drank the urine of their reindeer, rich in the unmetabolized psychoactive constituents of the mushrooms they foraged on prior to collection, for their hallucinogenic effect [48]. Another way shamans reportedly obtained the desired effect was by quickly slaughtering and eating the meat of animals intoxicated by the mushrooms [47]. Also in Siberia, the urine of fellow humans who ingested $A$. muscaria was taken in order to maximize or prolong the hallucinogenic effects [48]. One dose of $A$. muscaria is said to be passed through the urine of 4-5 people for its hallucinogenic effect [49]. The mushroom was also said to be ingested by the Khanty to increase strength for hunting and other strenuous activities like walking long distances and enduring cold temperatures [48].

These mushrooms contain ibotenic acid, its breakdown product, muscimol, and other constituents that exhibit sedative-hypnotic, depressant and hallucinogenic psychoactivity. The acid is noted to produce feelings of euphoria, muscle jerks, drowsiness, sweating, pupil dilation, and increased body temperature, symptoms which appear 30 to 90 minutes after consumption and are said to be most intense after two or three hours [50].

The description of the effect of giving a bear 'courage' could be the perception of the observer based on the bear's behavior and perhaps their own experience, due to the plant's intoxicating properties in both a lowering of inhibition and inducing a sense of strength, real or not. A reduction of fear would be of benefit to the bear when competing for mates. Competition is high and interactions between males and females at mating time can be violent, as males are known to kill young cubs to induce females to resume reproductive cycling [51-53].

More detailed information is needed to further understand the ecological context of its consumption, but as we will see from further examples, animals are known to ingest a variety of plants with stimulant or mildly hallucinogenic properties that could promote alertness and temporarily enhance a feeling of wellness under periods of environmental or social stress. These effects, however, could also be side effects of the plant being ingested by the animals for other reasons, but for humans the functions are clearly expressed.

Based on the available information, this behavior is tentatively classified as Mode 3, as a stimulant or tonic food, since there is no 
mention of animal use in relation to a physical disability. The health maintenance effect could be derived from the short-term rejuvenating or energy-giving properties of a stimulant. The alkaloids in many hallucinogenic substances could also serve to suppress parasite infections.

\section{Banisteriopsis caapi (Spruce ex Griseb.) C. V. Morton (Malpighiaceae): jaguar}

Some Amazonian people credit their uses of Banisteriopsis caapi, also widely known as 'ayahuasca,' from watching jaguars [14]. In the Amazonian rainforest, jaguars have been filmed gnawing on the bitter roots, bark and leaves of this plant, after which they appear dazed, rolling on their backs (www.youtube.com/watch? $\mathrm{v}=\mathrm{OqGDv0KCJ}$ (8). A similar behavior reported in many felid species, including domestic cats, is the frenzy induced by catnip ( $\mathrm{Ne}$ peta cataria L.) or silver vine (Actinidia polygama [Siebold \& Zucc.] Planch. ex Maxim.), which are reported to also have mosquitoand bedbug-repellent activities [54, 55].

The plant is used by shamans of the Tukano and other Amazonian cultures in ritualistic ceremonies and by hunters to heighten alertness and vision. It is said to give them 'jaguar eyes', or the ability to see well in the darkness of the forest for more effective hunting. This is supported by the plant's effect of dilating the pupils, which could enhance night vision and looking for prey in the dark forest. Among the Tukano, the hallucinogenic properties were used as a means of facilitating contact with the spirit world and inducing a shaman's healing powers. Ayahuasca is now used recreationally around the world for its mind-altering properties $[14,56,57]$. It is also used as a purgative, effectively removing parasites and toxins from the digestive tract [14]. Use of the plant by jaguars may also potentially induce antiparasitic action.

The vine contains hallucinogenic alkaloids (e.g., beta-carboline alkaloids, including harmine, harmaline and delta-tetrahycroharmine) and exhibits antiparasitic, emetic, and purgative actions $[56,57]$.

Jaguars' ingestion of ayahuasca can tentatively be classified as Mode 3 self-medication, for many of the same reasons given above, or possibly Mode 4 if evidence were available to show jaguars using the plant were doing so directly for its anthelmintic properties. However, more detailed information is needed to further understand the context of jaguars and other animals consuming plants with hallucinogenic properties by; for example, do they hunt afterwards, or do they ingest plants when parasite levels are high, and does it subsequently lower these levels? The plant's properties could promote alertness or simply be a byproduct of Jaguars' hedonic attraction to the plant, with the functional value being its antiparasitic properties. These pharmacological properties lend support to the functional aspects of the plant for jaguars, but more work needs to be done to understand the possible adaptive value of hallucinogen ingestion in animals.

\section{Catha edulis (Vahl) Endl. (Celastraceae): domestic goat}

According to folklore, a Yemenite herder called Awzulkernayien saw goats in his flock become much more active and move about tirelessly after chewing on the leaves of $C$. edulis. Curious about this, Awzulkernayien chewed on the leaves himself and felt renewed energy, even after a long day's work following the herd
[14]. These effects have since been demonstrated in human and animal trials [58].

This plant is a banned substance in Europe and North America but is still used widely in East Africa and across the Middle East under the names khat, chat, Absyssinian tea, qat, qaad, Arabian tea and others, as a mild stimulant producing euphoria [59]. Khat is used to fight off fatigue, improve work performance, and stay awake, and is also thought to improve mental performance. Yemeni khat chewers believe that it is also useful for other ailments like headaches, colds, body pains, fevers, arthritis, and depression [58].

The plant contains more than 40 alkaloids, terpenoids, flavonoids, sterols, glycosides, tannin, and amino acids. The amphetamine-like alkaloids (phenylalkylamines, cathedulins) are most responsible for the narcotic properties of the plant, which resemble those of cocaine, causing grandiose delusions, paranoia, nightmares, hallucinations, and hyperactivity $[14,58,60]$.

This plant can also tentatively be classified as Mode 3 . The plant's pharmacological properties lend support to the folklore. Health maintenance properties for animals could possibly include some of the ailments noted above by khat chewers, but more detailed observations are needed to understand the context of consumption by goats, to know whether is it accidental, seasonal or context-specific.

\section{Coffea arabica L. (Rubiaceae): domestic goat}

According to folklore, somewhere in present day Ethiopia a young goat herder named Kaldi saw old and young members of his flock friskily moving about after eating the red berries from a wild coffee bush. Hearing this, an abbot in the local monastery obtained some of the beans, roasted and brewed them as a hot drink. He named this 'Kahveh' (stimulating, invigorating), from which the words 'café' and 'coffee' are derived [14,61, 62]. Apparently, the members of the monastery found it helpful in preventing drowsiness during nightlong religious ceremonies.

The center of genetic diversity of $C$. arabica is in the highlands of southwestern Ethiopia, the Boma Plateau of Sudan and Mount Marsabit in Kenya, but today coffee is consumed worldwide as a caffeinated drink to fight off fatigue and to promote mental clarity. An Arabian physician, Razes, first mentions coffee in the 10th century, but it has been used most likely for the last 1500 years in southwestern Ethiopia. Elsewhere in Africa, coffee berries crushed and mixed with fat were served as a food to stimulate warriors in battle. Around 1000 AD in Yemen, coffee drinking became a widespread social ritual among Muslims. From the Middle East it spread to Europe and North, Central and South America [63, 64].

Caffeine and the related methylxanthines theobromine and theophylline are alkaloids widely distributed in plants throughout the world. Its value to wild animals as a stimulant to combat fatigue could be adaptive. Gorillas in the wild show preference for the seeds (nuts) of Cola pachycarpa K. Schum. and C. nitida (Vent.) Schott \& Endl. These seeds usually contain caffeine (2-2.5\%) and theobromine. The amino acid content of Kola 'nuts' indicates that protein levels are low, suggesting that gorillas may be eating the fruits and seeds not for nutrition, but primarily for their high caffeine content $[65,66]$. 
The example of goats eating coffee berries fits Mode 3, based on the behavioral information in the folklore linking the physiological properties of berries to the behavior of the individuals ingesting it. Here too, the health maintenance effect could be derived from the short-term rejuvenating or energy-giving properties of caffeine.

\section{Epimedium sagittatum (Siebold \& Zucc.) Maxim. (Berberidaceae): domestic goat, Tibetan macaque}

According to Chinese folklore, the properties of this plant were first recognized when herders saw their male goats becoming sexually excited after ingesting the leaves [14]. Tibetan macaques in China have also been reported ingesting this plant, at a time of year when mating activity is high but conceptive reproduction is at a seasonal all-time low [67]. This macaque species is known for its diversity of conflict-reduction behavior involving sexual behaviors, suggestive of high levels of social stress, which could possibly be regulated by the consumption of this plant.

Known by the common name Yin Yang Huo (淫羊雚) or hornygoats weed, this species is used in TCM as the most potent herb for enhancing male and female reproductive health. It is prescribed as a treatment for erectile dysfunction, to increase postmenopausal estrogen levels, and to treat osteoporosis [68, 69].

The plant contains the well-researched compounds, Icariside II (Baohuoside I) and Baohuoside II, III, V, VI [70]. These compounds demonstrate effects that are osteoprotective, neuroprotective, cardiovascular protective, anticancer, anti-inflammatory and immunoprotective, enhance reproductive function, and promote sexual health for both males and females $[68,71]$. Significant stress reduction and antidepressant properties via downregulation of glucocorticoid receptor activity and regulation of hippocampal neuro-inflammation have also been demonstrated [7274]. The leaves of this species are also noted for their immunosuppressive action and inhibitory properties of lymphocyte activation [75].

There is ample pharmacological evidence to support both animal and traditional human uses of this plant for its reproductive properties and potential stress reduction. Given the preliminary information gathered from the Tibetan macaques, which supports the folklore, I would tentatively classify this as a Mode 3 or 4 self-medicative behavior, depending on the situation-specific therapeutic potential for animals in the wild.

\section{Erythroxylum coca Lam. and related spp. (Erythroxylaceae): llama, three-toed sloth, Hoffmann's two-toed sloth}

According to Peruvian folklore, the origin of coca use is credited to the observation of llamas ingesting the leaves of this plant when moved to lower elevations in the Andes, eating the abundantly available leaves for lack of their typical high-altitude foods. The herders observed that these leaves gave their llamas extended stamina, and tried them themselves, obtaining similar effects. Other folk tales attribute human use of coca to watching sloths and monkeys consume the leaves [14]. This suggests ingestion by a number of different animal species and thus possibly multiple discovery of events by people and animals in different areas across the plant's distribution.
The leaves of coca are commonly chewed in Andean life as a stimulant and have been suggested to be in use for at least the last 1000 to 3000 years, but possibly even as early as 5000 BCE, when Ilamas were first domesticated. The Aymara people, an indigenous population of the Andes and Altiplano regions of South America, use them as a treatment for altitude sickness, to reduce hunger pains and fatigue, as a fast-acting antidepressant, and to increase sexual vigor, among other things $[14,76,77]$. Coca leaf has been described as a comprehensive remedy for restoring balance to the digestive system. The masticated leaves are held in the mouth to relieve and help heal painful oral sores and lesions, and also used for toothaches [76].

The leaves of the plant contain eighteen alkaloids. Best known is the psychoactive constituent, cocaine $[76,78]$.

Given the preliminary information available from the folklore, coca-leaf consumption could be classified as Mode 3, possibly 4, with the possibility that ingestion of the plant could provide either stimulation or specific therapeutic relief from symptoms experienced by the animal. Further observations of the context and outcome of plant ingestion would be necessary to better explain the function of this behavior for animals consuming these leaves.

\section{Ligusticum porteri J. M. Coult. \& Rose (Apiaceae): black bear, brown bear, Kodiak bear}

According to indigenous North American folklore, the bear introduced this medicine, called 'Osha,' to them. One account is that bears consume the roots of the plant after emerging from winter hibernation in a weakened state, to restore strength or when wounded or sick [79]. Behavioral observations in captivity have shown that when presented with the root, bears will chew it, and then, mixed with saliva, rub it into their fur [14]. The roots are chewed by several indigenous tribes in the western United States to increase endurance and to ease breathing at high altitudes, for long-distance walking, and related pain. In current phytotherapies, it is also used as an antiviral, antibacterial, antifungal, and anti-inflammatory agent. It is also used as an antiseptic for abrasions, open wounds, superficial infections, as a stomach bitter for indigestion, to support healing of respiratory conditions (coughs, colds, sore throats, tonsillitis, flu), and other types of viral infections, including herpes and HIV [80-84].

The roots contain volatile and fixed oils, lactone glycosides, alkaloids, phytosterols, saponins and ferulic acid [81]. The compounds Z-ligustilide and butylidenephathalide are most commonly attributed to the plant's therapeutic effect [85].

Due to a lack of field studies on this behavior in bears, we have only the captive studies to depend upon for direct ethological information. Given the apparent lack of nutritional value in the way the roots are utilized, and the secondary compounds they are known to contain, use of the roots can tentatively be classified as a Mode 4 form of therapeutic self-medication.

\section{Ophiocordyceps sinensis [Berk.] Sung GH et al. (formerly known as Cordyceps sinensis) (Ophiocordycipitaceae): yak}

According to Chinese folklore, yak herders discovered the use of this fungus for enhanced vigor after observing the effects on yaks eating them at the beginning of their breeding season [14]. 
The fungus is widely used in Ayurvedic medicine and TCM for enhancing vigor and vitality. The name of the medicine means winter worm - summer grass (冬蟲夏草), denoting that the medicine is the product of a fungus that infects caterpillars of moths (Hepialidae). In winter, the fungi infect the caterpillars, and the growth protrudes from the head of the paralyzed or dead caterpillar in early summer. Humans collect these infected caterpillars, dry and crush them into powder. After long-term treatment, chronic immune and respiratory ailments are said to be relieved. Traditional healers in the Himalayas of China, Nepal. and Bhutan use this to increase longevity, to treat infertility and erectile dysfunction, and as a female aphrodisiac. It is also used to treat general weakness, tuberculosis, bronchitis, malignant tumors, coughs and colds, rheumatism, arthritis, jaundice, prostate enlargement, liver diseases, kidney diseases, coronary heart disease, chronic pain, sciatica and backache, high blood pressure, dizziness, and diabetes-related high blood sugar levels [86]. The product is so widely used that I was able to purchase it in processed powder formulations at 7-Eleven stores in downtown Taipei as a treatment for the common cold.

The fungus contains cordycepin, cordycepic acid, glutamic acid, amino acids, polyamines, cyclic dipeptides, saccharides and sugar derivatives, sterols, 28 saturated and unsaturated fatty acids, their derivatives, and other organic acids and vitamins. Some demonstrated properties include anti-inflammatory, antioxidant, antitumor, anti-apoptotic and immunomodulatory actions [86, 87].

From the available information, it is difficult to discern the function of self-medication this behavior represents in yak, but for humans the majority of uses suggest a Mode 4 self-medicative therapeutic treatment for an animal that ingests the fungus. More information is needed to draw any conclusions of the self-medicative value to yak, but it can at least tentatively be classified as a Mode 3 self-medicative behavior for now.

\section{Piliostigma thonningii (Schum.) Milne-Redh. (Caesapilioideae): elephant}

Called 'Munyonga nTembo' by the WaTongwe, this is a medicinal plant used by them to treat for stomach problems. The origin of the name of this plant comes from the Tongwe verb 'kunyonga' (literally to kill, but here meaning to pull out of the ground, or twist off) and the Swahili 'tembo' (elephant). Elephants twist and pull out small saplings or pull off the leaves of big trees with their trunks before processing them. One day Babu Kalunde, the grandfather of Mohamedi, observed an elephant suffering from stomach upset. The elephant put a few bunches of the plant's leaves into its mouth, chewing them up a bit without swallowing them. The elephant then took in some water with its trunk and transferred both the leaves and water into its pharyngeal pouch (an organ used for storing a few liters of water located in the neck area). After holding the leaves and water together for some time, it discarded the leaves and swallowed the water. From that point on, Babu Kalunde and other Tongwe herbalists began to use the water extract of Munyonga nTembo, or its thoroughly crushed leaves as a suppository for stomach upset [17].

Across Africa the plant is used to treat malaria, dysentery, intestinal upsets, diarrhea, flatulence, fever, respiratory infections, snakebite, hookworm, and skin diseases, among others [8, 8890]. Broad-spectrum antibacterial activity against Staphylococcus aureus, Bacillus subtilis, Pseudomonas aeruginosa, Streptococcus pyogene, Proteus vulgaris, Salmonella typhi and Escherichia coli have been reported from leaf, bark and root extracts [91]. Sesquiterpenes and monoterpene hydrocarbons, monoterpenes and sesquiterpene hydrocarbons are the chief class of terpenoids isolated from the leaves [90].

This behavior is suggestive of Mode 4 form of therapeutic selfmedicative behavior based on the specific symptoms at the time of use. Not much more can be said without more elephant behavioral data or pharmacological studies of the plant, but free-ranging Asian elephants under the care of Mahouts in Thailand are also known to select herbs from the forest specifically for stomach upset, and the Mahouts will collect and use those plants for treatment of the elephants and themselves [92].

\section{Shilajit: Nepal langur}

It is said that long ago Himalayan villagers observed langurs in the mountains during warm summer months chewing on the semisoft resinous substance known as Shilajit oozing out from between layers of rock on cliffs. Wild Nepal langurs across the Himalayas can be observed licking the resin from rock faces in their high-altitude habitats. The villagers attributed the monkey's great strength, longevity, and wisdom to the use of this substance. People began to consume the substance themselves, experiencing a broad spectrum of health benefits, including increased energy, relief from digestive problems, increased libido, enhanced memory and cognitive function, improvement of diabetes, reduction of allergies, and increased longevity [93].

Shilajit is used as a traditional medicine for a number of its important pharmacological activities [94]. It is a complex mixture of organic humic substances, plant and microbial metabolites occurring in the rock rhizosphere of high-altitude habitats between 1000-5000 metres. Two plant species, Euphorbia royleana Boiss. (Euphorbiaceae) and Trifolium repens L. (Leguminosae), are specifically mentioned; however, mosses such as Barbula, Fissidens, Minium and Thuidium, and liverworts such as Asterella, Dumortiera, Marchantia, Pellia, Plagiochasma and Stephenrencella-Anthoceros are also included.

Shilajit is a widely used treatment in Ayurvedic medicine, dating back to at least 1000 BCE for phthisis, chronic bronchitis, asthma, digestive troubles, bladder calculi, edema, nervous diseases, leprosy, diabetes, bone fractures, parasitic diseases of the skin, as an antiphlogistic and as a memory enhancer $[93,95,96]$. It is also found and used in Russia, Tibet, Afghanistan and in the north of Chile. The Sherpa, high-altitude porters and mountain guides of Nepal, include shilajit in their diet [97].

Many of the Aryuvedic uses have been validated in the laboratory. These activities include immunomodulation, improvement of cognitive function, anxiolytic, antiviral, anti-inflammatory, antifungal, and analgesic effects, and the reduction of chronic fatigue [95, 97].

There is no specific illness mentioned in the folklore that langurs may be targeting when ingesting the substance. Based on preliminary observations of langurs living at high altitude in the Himalayas, I would tentatively classify this as a Mode 3 self-medi- 
cative behavior for its possible use as a stimulant or tonic food, beneficial for living at high altitudes.

\section{Tabernanthe iboga Baill. (Apocynaceae): boar spp., porcupine, western lowland gorilla}

According to locals and European hunters in Gabon and the Congo, gorillas, porcupines, and boars dig up the roots of this plant, chew on them and subsequently go into a wild frenzy, jumping around and fleeing as if being chased by something $[66,98]$.

The hunter-gatherers are said to have passed this information on to the farming communities in the past. This plant is still an essential component of religious rites, particularly 'Bwiti'. The Metsogho-Massango and Bapinzi peoples of southern Gabon practice Bwiti in its original form [99]. Local inhabitants of the Peti Loango region of coastal Gabon use $T$. iboga for a similar ritual called 'Bouiti' in their secret society rituals [66]. People cultivate the plant in their gardens for use as an energizer, stimulant and hallucinogen [14].

The key active ingredients are ibogaine, tabernanthine, and iboluteine. These affect the central nervous system and cardiovascular system, and increase stamina. They contain psychoactive properties and act as an interrupter for drug addiction without withdrawal symptoms $[14,66]$. Experimentally injected into dogs, ibogaine induces fear behavior (as if they were seeing frightening things), sudden barking out loud for no apparent reason, leaping backwards or desperately trying to hide in a corner. Experimentation with frogs and guinea pigs produced effects similar to those from a large dose of caffeine $[100,101]$.

Use of the roots by animals does not appear to be nutritional, based on the intense responses shown and demonstrated bioactivity of the substances they contain. At the moment, the medicinal value cannot be clearly determined, but could tentatively be classified as a Mode 3 behavior with unknown function(s). This type of ingestive behavior, like other examples reported above and elsewhere, remains an enigma in need of further investigation. Its potential adaptive value may provide insights for possible uses for humans and livestock.

\section{Terminalia kaiseriana F. Hoffm. (Combretaceae): bush pig}

Similar to the story of mulengelele, the origin of this plant's use by the WaTongwe of western Tanzania, was discovered by a hunter who observed a wild boar suffering from diarrhea digging up and ingesting the roots of the plant. The boar was followed, and subsequently, over a few days, was observed to recover [17].

WaTongwe traditional healers now use this plant for the treatment of cholera or extreme diarrhea. The intensely bitter roots and bark are crushed and put into water, to be drunk or used as an enema [17]. Elsewhere in East Africa, the roots, stem bark, and leaves are made into a hot water tea, or mixed with maize porridge for the treatment of various infectious diseases and their symptoms, e.g., diarrhea and cough [102]. They are also used elsewhere in Tanzania to treat for malaria, skin disease [103], schistosomiasis, and gonorrhea [88, 104].

The crude methanol extract of the roots shows promising antimicrobial effects against Staphylococcus aureus, with MIC values of $625 \mu \mathrm{g} / \mathrm{ml}$. An ellagitannin-enriched Lobar RP-8 CC fraction of the roots effectively inhibits the growth of the pathogenic $S$. aureus with a MIC value of $250 \mu \mathrm{g} / \mathrm{ml}$ [105].

The ingestion of $T$. kaiseriana by bushpigs can be tentatively classified as Mode 4 of therapeutic self-medicative behavior, given the plant's pharmacological properties and the curative contextspecific use by the wild boar.

\section{Trema orientalis (L.) Blume: chimpanzee}

In the course of my research at Mahale, Mohamedi and I have closely followed numerous chimpanzees over the course of their illness to full recovery or death. In 2003, I was able to witness firsthand the acquisition of a new medicine by Mohamedi as a consequence of our observations of the use of a plant by one such chimpanzee suffering from a strongyle nematode infection. The plant, locally known as mhefu, is a common pioneer tree species found in recently cleared forests or on the edge of fields. It is one of the plants whose rough leaves are swallowed whole by chimpanzees for the physical expulsion of strongyle nematodes by chimpanzees at Mahale $[106,107]$. Chimpanzees swallow the rough leaves of this plant and eight other rough-surfaced species available in their habitat on an empty stomach without chewing them. This stimulates the GI tract to fast-track evacuation of the contents of the large intestine, resulting in the physical purging of the nodule worm, O. stephanostomum, along with the intact leaves of this plant [107].

This was the first time we witnessed chimpanzees swallowing the rough leaves of $T$. orientalis, and Mohamedi was curious about the plant. Prior to then, the WaTongwe in this area did not recognize it as medicine. After tearing a leaf and sniffing, he took a pocket full of them home and prepared a water extract from the crushed leaves to see how they would work to stop diarrhea. He found the extract to be quite effective. At first his mother, Joha Kasante, also a traditional healer, was skeptical that it would be of any medicinal value, not because an animal used it as medicine, but because she knew the tree only as a good source of firewood and building material. Convinced by its effectiveness, the elderly mother and son began to use it in their medicinal practices.

Interestingly, a water decoction of the leaves is used elsewhere as an anthelminthic treatment for roundworms and hookworms in West Africa, East Africa, and some parts of Central Africa and Madagascar. The plant contains tannins, saponins, flavonoids, triterpenes and several other active constituents with analgesic, anti-inflammatory, plasmodicidal, anthelmintic, and antibacterial activity, and also has a laxative effect [108].

In chimpanzees, the swallowing of whole leaves of $T$. orientalis without chewing them is classified as a Mode 4 therapeutic selfmedicative behavior for the expulsion of nematodes [107]. This behavior is widely observed across Africa for the same purpose by the other great ape species (gorillas and bonobos), using over 40 different species of plants [21,31].

It was not the goal of this paper to recommend new treatments for animals or to demonstrate that these examples are conclusive cases of self-medication. Nonetheless, in my estimation, all of the case studies presented were consistent with the behavior of these species and are worthy of future research as possible candidates of self-medication. Based on the available information, each of the 14 cases could be classified into either Mode 3: stimulant, 
tonic foods $(\mathrm{N}=7)$, Mode 4: therapeutic treatment $(\mathrm{N}=5)$ or possibly both modes $(\mathrm{N}=2)$ of self-medicative behavior ( $\bullet$ Table 1$)$.

The variety of case studies presented here from folklore and modern day examples of the acquisition of medicinal plants by humans observing wild and domestic animals, reportedly to selfmedicate, speak to a wider pattern around the world. This provides a new perspective into the role animals have played in the formulation of our medicinal heritage, based on the understanding that animals, too, self-medicate to stay healthy. It is impossible to say what proportion of our medicinal heritage we owe to the observation of animal self-medication, but there should be no doubt that it has played a role in the past and continues to play a role even today in some societies.

In our species' early history, when faced with the urgent need to treat a sickness for which there was no known cure, choosing a possibly poisonous plant such as mulengelele ( . cristata) would have been made easier if a sick animal with similar symptoms was seen to ingest it and recover. This would have been less risky than randomly selecting unfamiliar plants in the habitat. Once learned, humans, like many other animals, learn from experience and pass this information down from one generation to the next in an environment-specific context [109]. The contemporary case study of $T$. orientalis use by chimpanzees leading to the traditional healer's use of it, and the widespread similar use of this plant across other parts of Africa, nicely illustrates the fact that medicinal plants can have multiple independent and other animal-dependent origins.

These few case studies suggest that some plants might have been ingested for health maintenance as stimulants or tonics to fight off hunger, fatigue, improve reproductive potential and lower stress, or as therapeutic agents for internal and external parasite infections and wounds. The goal of this article was not to recommend specific treatments as veterinary phytotherapies. Instead, it was my wish to demonstrate the usefulness of animal self-medication studies in understanding the animal origins of our species' medicinal behavior and at the same time, to generate potential interest in new avenues for innovating and improving upon phytotherapies for the basic well-being of humans and livestock from this method.

As we look to the future, we can be reminded of these examples, showing us that the activities of even well known medicinal plants can reveal new uses for them. For example, L. porteri, the bear medicine, is known to possess significant antiviral, antibacterial. and antifungal properties. The active ingredients of this plant are sold today as alcohol tinctures in natural health food stores as a source of lactone glycoside and saponins for the treatment of respiratory illness and sore throats. This has particular relevance to our situation under the COVID-19 pandemic. During the last global pandemic of 1918 (Spanish Flu), a species closely related to L. porter, Lomatium dissectum (Nutt.) Mathias \& Constance, was traditionally used by the Washoe, a Northern Paiute tribe in Arizona, to treat viral respiratory illness. This caught the attention of Western medical doctors in the region in 1918 because the Washoe used this plant to successfully treat H1N1 virus. Reportedly, no one treated with it died of the flu. L. dissectum is phytochemically and therapeutically similar to $L$. porteri, both containing the bioactive lomatiums, reputedly some of the most potent antiviral com- pounds active against influenza known in herbal medicine today [12].

The examples presented in this paper convey the importance some traditional societies have put on animal behavior as a source of medicinal wisdom, and provide clues as to how scientists can now advance this line of approach for use in modern phytotherapeutic treatments. Observation of wild animals can be argued to represent millions of years of in situ experimentation. The scientific approach of zoopharmacognosy could help to alleviate some of the ethical questions of laboratory animal drug tests, and importantly, aid in the fight of drug resistance using phytotherapies. In recent years, the practice of Applied Animal Self-Medication has come of age. Practitioners and teachers like Caroline Ingraham in the U.K. $[110,111]$ have made significant strides in using the paradigm of an animal's ability to self-medicate, by presenting ill individuals with choices, allowing them to self-select and self-dose from an array of essential oils, herbal and mineral options known to treat the appropriate illness. This has met with success in the treatment of a wide range of ailments in both wild and domestic animals.

I have spent much of the last three decades studying wild animals around the world trying to better understand what makes them sick, what they do when they are sick, and what do they use to regain health. In the process, I have come to appreciate the wisdom of traditional cultures living much closer to the "natural' world than most of us do today. By combining millions of years of natural selection in the animal kingdom with the accumulated knowledge of modern and traditional human health care systems, we have much to benefit from the important relationships between humans, animals and plants. Through scientific evaluation and validation of information long considered folklore, new applications from old therapies, and even new ones, can be found.

I would like to suggest that this marriage of the old and the new, borrowing and integrating the skills of many fields, is a holistic paradigm with promise. As long as people are curious about nature and believe it has something to teach us, we have a chance at saving it along with ourselves.

\section{Material and Methods}

Fourteen case studies were extracted from Engel's Wild Medicine (2002) and my own research (Huffman 2007), of ethnomedicines purportedly acquired from the observations of their use by animals. The main criteria for the selection of examples from the folklore were geographical, cultural, and animal taxonomic diversity, as well as a putative mode of self-medication. The case studies are listed in alphabetical order by plant species or common name, when species name was not available. From these 14 case studies, over 20 animal species and numerous human cultures from around the world are represented ( $\vee$ Table 1 ). Plant species names and authorities were verified using Plants of the World Online, facilitated by the Royal Botanic Gardens, Kew (www.plantsoftheworldonline.org/). Pharmacological and therapeutic value of the plants was further investigated using Google Scholar to find relevant publications. A variety of medicinal plant databases was also used (see reference list). 
- Table 1 Case studies of ethnomedicinal plants in folklore and ethnographical studies purportedly derived from observed instances of animal selfmedication.

\begin{tabular}{|c|c|c|c|}
\hline Plant species & $\begin{array}{l}\text { Animal species (Mode of } \\
\text { self-medication) }\end{array}$ & Ethnomedicinal uses & $\begin{array}{l}\text { Observed animal behavior leading } \\
\text { to its use by humans }\end{array}$ \\
\hline $\begin{array}{l}\text { Aeschynomene cristata } \\
\text { Vatke var. cristata } \\
\text { (Fabaceae) }\end{array}$ & $\begin{array}{l}\text { Crested porcupine (Hystrix } \\
\text { africaeaustralis; } \mathrm{H} \text {. cristata) } \\
\text { (therapeutic treatment: } 4 \text { ) }\end{array}$ & $\begin{array}{l}\text { Antibiotic properties suggested. Root concoc- } \\
\text { tion used to treat patients with sexually trans- } \\
\text { mitted disease and other illnesses with symp- } \\
\text { toms resembling dysentery in East Africa. Used } \\
\text { as a treatment for secondary infections in AIDS } \\
\text { patients. }\end{array}$ & $\begin{array}{l}\text { Porcupine dug up and ingested the toxic } \\
\text { root. It subsequently recovered from } \\
\text { dysentery-like symptoms (bloody stools). }\end{array}$ \\
\hline $\begin{array}{l}\text { Amanita muscaria (L.) } \\
\text { Lam. (Amanitaceae) }\end{array}$ & $\begin{array}{l}\text { Reindeer, Caribou (Rangifer } \\
\text { tarandus) Brown bear (Ursus } \\
\text { arctos; Ursus spp.) (stimu- } \\
\text { lant, tonic food: 3) }\end{array}$ & $\begin{array}{l}\text { Hallucinogenic effect used to communicate with } \\
\text { the spirit world and to meet powerful spirits with } \\
\text { 'courage'; induces a temporary sense of eupho- } \\
\text { ria. Used to increase strength for hunting, walk- } \\
\text { ing long distances, and enduring cold tempera- } \\
\text { tures. }\end{array}$ & $\begin{array}{l}\text { After eating the mushrooms, reindeer } \\
\text { move around as if intoxicated. In the } \\
\text { mating season, bears that ingest them } \\
\text { are said to act with 'courage', losing the } \\
\text { inhibition to confront others. }\end{array}$ \\
\hline $\begin{array}{l}\text { Banisteriopsis caapi } \\
\text { (Spruce ex Griseb.) C.V. } \\
\text { Morton (Malpighiaceae) }\end{array}$ & $\begin{array}{l}\text { Jaguar (Panthera onca) } \\
\text { (stimulant/therapeutic } \\
\text { treatment: } 3 \text { or } 4 \text { ) }\end{array}$ & $\begin{array}{l}\text { Used in ceremonies for its hallucinogenic prop- } \\
\text { erties, to heighten alertness and night vision } \\
\text { ('jaguar' eyes) while hunting. Used as an anti- } \\
\text { parasitic treatment. }\end{array}$ & $\begin{array}{l}\text { After chewing on the bark and roots, } \\
\text { leopards roll on the ground in an intoxi- } \\
\text { cated state like cats with catnip. }\end{array}$ \\
\hline $\begin{array}{l}\text { Catha edulis (Vahl) Endl. } \\
\text { (Celastraceae) }\end{array}$ & $\begin{array}{l}\text { Domestic goats (Capra spp.) } \\
\text { (stimulant, tonic food: } 3 \text { ) }\end{array}$ & $\begin{array}{l}\text { Used as a mild euphoric stimulant, to minimize } \\
\text { fatigue, improve work and mental performance, } \\
\text { and to stay awake. Improves mental perfor- } \\
\text { mance and is thought to be beneficial for head- } \\
\text { aches, colds, body pains, fevers, arthritis, and } \\
\text { depression. }\end{array}$ & $\begin{array}{l}\text { After chewing on the leaves, goats friskily } \\
\text { run around at faster than normal speeds } \\
\text { seemingly filled with energy. }\end{array}$ \\
\hline $\begin{array}{l}\text { Coffea arabica L. } \\
\text { (Rubiaceae) }\end{array}$ & $\begin{array}{l}\text { Domestic goats (Capra spp.) } \\
\text { (stimulant, tonic food: } 3 \text { ) }\end{array}$ & $\begin{array}{l}\text { First consumed as a beverage for mental clarity, } \\
\text { and to counteract fatigue in the highland region } \\
\text { of present-day Ethiopia. }\end{array}$ & $\begin{array}{l}\text { After feeding on the red berries of the } \\
\text { wild coffee bush, goats become more } \\
\text { alert and move about friskily. }\end{array}$ \\
\hline $\begin{array}{l}\text { Epimedium sagittatum } \\
\text { Franchet (Berberidaceae) }\end{array}$ & $\begin{array}{l}\text { Domestic goats (Capra } \\
\text { spp.), Tibetan macaques } \\
\text { (Macaca thibetana) } \\
\text { (stimulant, tonic food: } 3 \text { ) }\end{array}$ & $\begin{array}{l}\text { Known as 'horny goats weed', the plant is widely } \\
\text { used in Traditional Chinese Medicine as the most } \\
\text { potent herb for enhancing male and female re- } \\
\text { productive health (erectile dysfunction, increas- } \\
\text { ing post-menoposal estrogen levels), and treat- } \\
\text { ing osteoporosis. }\end{array}$ & $\begin{array}{l}\text { Male goats become sexually excited after } \\
\text { ingesting this herb. Tibetan macaques } \\
\text { consume the leaves during the time of } \\
\text { year when mating persists but few con- } \\
\text { ceptions result. }\end{array}$ \\
\hline $\begin{array}{l}\text { Erythroxylum coca Lam. } \\
\text { (Erythroxylaceae) }\end{array}$ & $\begin{array}{l}\text { Llama (Lama glama), three- } \\
\text { toed sloth (Bradypus tridac- } \\
\text { tylus), Hoffmann's two- } \\
\text { toed sloth (Choloepus hoff- } \\
\text { manni) (stimulant/therapeu- } \\
\text { tic treatment: } 3 \text { or 4) }\end{array}$ & $\begin{array}{l}\text { Used in the Andes as a stimulant, treatment for } \\
\text { altitude sickness, abatement of hunger, reduc- } \\
\text { tion of fatigue, fast-acting antidepressant, in- } \\
\text { creases sexual appetite. It is used as a compre- } \\
\text { hensive remedy for restoring balance to the } \\
\text { digestive system. The masticated leaves are held } \\
\text { in the mouth for relief of painful oral lesions and } \\
\text { toothaches. }\end{array}$ & $\begin{array}{l}\text { Llama moved to lower elevations in the } \\
\text { Andes were observed to chew on coca } \\
\text { leaves as an alternative food source in the } \\
\text { new habitat. Herders observed that these } \\
\text { leaves appeared to give the llama ex- } \\
\text { tended stamina. Similar legends attribute } \\
\text { human use of coca for this purpose by } \\
\text { watching sloths and monkeys eat coca } \\
\text { and behave in a similar way to the llama. }\end{array}$ \\
\hline $\begin{array}{l}\text { Ligusticum porteri Coult. \& } \\
\text { Rose (Apiaceae) }\end{array}$ & $\begin{array}{l}\text { Black bear (Ursus ameri- } \\
\text { canus), Brown bear (Ursus } \\
\text { arctos), Kodiak bear (Ursus } \\
\text { arctos middendorffi) (thera- } \\
\text { peutic treatment: 4) }\end{array}$ & $\begin{array}{l}\text { Roots chewed to increase endurance. Possess } \\
\text { antiviral, antibacterial, antifungal and anti-in- } \\
\text { flammatory activities. Roots support healing of } \\
\text { respiratory conditions, indigestion, headaches, } \\
\text { dizziness, sinusitis, and arthritis. Taken to ease } \\
\text { breathing at higher altitudes, and for long-dis- } \\
\text { tance hiking. }\end{array}$ & $\begin{array}{l}\text { Bears consume the roots after emerging } \\
\text { from winter hibernation in a weakened } \\
\text { state, to restore strength, or when } \\
\text { wounded or sick. Roots are chewed, and } \\
\text { then, mixed with saliva, rubbed into their } \\
\text { fur to treat skin infection and possibly } \\
\text { wounds. }\end{array}$ \\
\hline $\begin{array}{l}\text { Ophiocordyceps sinensis } \\
\text { [Berk.] Sung GH et al. } \\
\text { (Cordyceps sinensis) } \\
\text { (Ophiocordycipitaceae) }\end{array}$ & $\begin{array}{l}\text { Yak (Bos grunniens) } \\
\text { (stimulant, tonic food: } 3 \text { ) }\end{array}$ & $\begin{array}{l}\text { Ayurveda and TCM medicine used for enhancing } \\
\text { vigor and vitality, erectile dysfunction, as a fe- } \\
\text { male aphrodisiac, to treat bronchitis, cough and } \\
\text { cold, rheumatism, arthritis, chronic pain, sciati- } \\
\text { ca, low blood pressure, dizziness, and diabetes. }\end{array}$ & $\begin{array}{l}\text { Fungus is eaten by yaks at the beginning } \\
\text { of the breeding season. }\end{array}$ \\
\hline
\end{tabular}


- Table 1 Continued

\begin{tabular}{|c|c|c|c|}
\hline Plant species & $\begin{array}{l}\text { Animal species (Mode of } \\
\text { self-medication) }\end{array}$ & Ethnomedicinal uses & $\begin{array}{l}\text { Observed animal behavior leading } \\
\text { to its use by humans }\end{array}$ \\
\hline $\begin{array}{l}\text { Piliostigma thonningii } \\
\text { (Schum.) Milne-Redh. } \\
\text { (Caesapilioideae) }\end{array}$ & $\begin{array}{l}\text { African elephant (Loxodonta } \\
\text { africana) (therapeutic treat- } \\
\text { ment: } 4 \text { ) }\end{array}$ & $\begin{array}{l}\text { Treatment for dysentery, intestinal upsets, } \\
\text { diarrhea, flatulence, malaria, fever, respiratory } \\
\text { infection, snakebite, hookworm, and skin dis- } \\
\text { eases, among others. }\end{array}$ & $\begin{array}{l}\text { Elephants suffering from gastrointestinal } \\
\text { disturbance chew on the leaves and tem- } \\
\text { porarily store them in their esophageal } \\
\text { pouch together with water. After leaving } \\
\text { to soak for a while, leaves are discarded } \\
\text { and the water is swallowed. }\end{array}$ \\
\hline Shilajit & $\begin{array}{l}\text { Nepal langur (Semnopithecus } \\
\text { schicstaceus) (stimulant, } \\
\text { tonic food: } 3 \text { ) }\end{array}$ & $\begin{array}{l}\text { Used as a prophylaxis for altitude sickness, } \\
\text { an Ayurveda treatment for chronic bronchitis, } \\
\text { asthma, digestive troubles, bladder calculi, } \\
\text { nervous disorders, diabetes, bone fractures, } \\
\text { skin parasite diseases, memory loss, prevention } \\
\text { of Alzheimer's disease. }\end{array}$ & $\begin{array}{l}\text { Langurs chew on the semi-soft resin-like } \\
\text { substance that oozes out from between } \\
\text { layers of rock on cliffs in the mountains } \\
\text { during warm summer months. }\end{array}$ \\
\hline $\begin{array}{l}\text { Tabernanthe iboga Baill. } \\
\text { (Apocynaceae) }\end{array}$ & $\begin{array}{l}\text { Boar spp. (Suidae), porcu- } \\
\text { pine (Hystrix africaeaustralis), } \\
\text { Western lowland gorillas } \\
\text { (Gorilla gorilla gorilla) and } \\
\text { Mandrills (Mandrilis sp.) } \\
\text { (therapeutic treatment: } 3 \text { ) }\end{array}$ & $\begin{array}{l}\text { A hallucinogen used in Central Africa in religious } \\
\text { cult ceremonies. Cultivated in vegetable gardens } \\
\text { for use as an energizer, stimulant, and hallucino- } \\
\text { gen. }\end{array}$ & $\begin{array}{l}\text { Gorilla, porcupine, and wild boar dig up } \\
\text { roots and chew on them, going into a } \\
\text { wild frenzy, jumping around, and fleeing } \\
\text { as if from something frightening. }\end{array}$ \\
\hline $\begin{array}{l}\text { Terminalia kaiseriana F. } \\
\text { Hoffm. (Combretaceae) }\end{array}$ & $\begin{array}{l}\text { Bush pig (Phacochoerus afri- } \\
\text { canus) (therapeutic treat- } \\
\text { ment: } 4 \text { ) }\end{array}$ & A treatment for cholera (extreme diarrhea). & $\begin{array}{l}\text { Wild boar with diarrhea dig up and ingest } \\
\text { the roots. They subsequently recover. }\end{array}$ \\
\hline $\begin{array}{l}\text { Trema orientalis Linn. } \\
\text { Blume, (Ulmaceae) }\end{array}$ & $\begin{array}{l}\text { Chimpanzee (Pan troglodytes } \\
\text { schweinfurthi) (therapeutic } \\
\text { treatment: } 4 \text { ) }\end{array}$ & $\begin{array}{l}\text { A decoction of the leaves is used as an anthel- } \\
\text { minthic medicine for roundworms and hook- } \\
\text { worm. Also used to treat diarrhea. }\end{array}$ & $\begin{array}{l}\text { Chimpanzees suffering from heavy } \\
\text { strongyle nematode burden, fold, and } \\
\text { swallow leaves whole, expelling adult } \\
\text { worms within } 6 \text { hours. }\end{array}$ \\
\hline
\end{tabular}

\section{Contributors' Statement}

I am solely responsible for the conception and design of the work, data collection, analysis and interpretation of the data, drafting the manuscript, critical revision of the manuscript.

\section{Acknowledgements}

I am grateful to Editor-in-Chief, Prof. Robert Fürst, Editor Prof. Marek Murias and the Guest editors for the invitation to prepare this article. Also I am grateful to the five reviewers for their helpful suggestions and recommendations along the way. The manuscript benefited greatly from their multidisciplinary input. I also thank Keith Riggle for his insightful questions and comments on the content and kind attention to the grammatical structure. I owe many thanks to Kudra Katensi for relaying my questions to the elders of Katumbi and Buhingu villages on the shores of Lake Tanganyika for clarification about the details of Myonga Ntembo while I was revising this article. I thank Frank Mbago, Head Curator of the Herbarium at the University of Dar es Salaam for the identification of Piliostigma thonningii from photographs also provided by Kudra. Last, but certainly not least, I dedicate this paper to the memory of my dear friend, the late Mohamedi Seif Kalunde, his mother Joha Kasante, and his grandfather Babu Kalunde Mohamedi Seif, members of a long line of traditional healers who looked to animals for medicinal inspiration.

\section{Conflict of Interest}

The authors declare that they have no conflict of interest.

\section{References}

[1] Hardy K, Buckley S, Collins M], Estalrrich A, Brothwell D, Copeland L, Garcia-Tabernero A, Garcia-Vargas S, De La Rasilla M, Lalueza-Fox C, Huguet R, Bastir M, Santamaria D, Madella M, Cortes AF, Rosas A. Neanderthal medics? Evidence for food, cooking, and medicinal plants entrapped in dental calculus. Naturwissenschaften 2012; 99: 617-626

[2] Hardy K. Paleomedicine and the use of plant secondary compounds in the Paleolithic and Early Neolithic. Evol Anthropol 2019; 28: 60-71

[3] Narayanaswamy V. Origin and development of Ayurveda (A brief history). Anc Sci Life 1981; 1: 1-7

[4] Yen KY. The illustrated Chinese Materia Medica: Crude and Prepared. Taipei: SMC Publishing Inc.; 1992

[5] Yang S. The Divine Farmer's Materia Medica: A Translation of the Shen Nong Ben Cao Jing. Boulder, CO: Blue Poppy Press; 1998

[6] Khare CP. Ayurvedic Pharmacopoeial Plant Drugs. Expanded Therapeutics. Boca Raton: CRC Press; 2016

[7] WHO. WHO global report on traditional and complementary medicine 2019. Geneva: World Health Organization; 2019

[8] Neuwinger HD. African Ethnobotany: Poisons and Drugs. London: Chapman \& Hall; 1994

[9] Schultz V, Hansel R, Tyler VE. Rational Phytotherapy. A Physicians' Guide to Hherbal Medicine. Berlin: Springer; 1998

[10] Johnson T. CRC Ethnobotany Desk Reference. London: CRC Press; 1999

[11] Buhner SH. Herbal Antibiotic. North Adams, MA: Storey Publishing LLC; 2012

[12] Buhner SH. Herbal Antivirals: Natural Remedies for Emerging \& Resistant Viral Infections. North Adams: Storey Publishing LLC; 2013 
[13] McGaw L], Abdalla MA. Ethnoveterinary Medicine - Present and Future Concepts. Cham: Springer; 2020

[14] Engel C. Wild Health. Boston: Houghton Mifflin; 2002

[15] Christie A. Chinese Mythology. London: Hamlyn; 1975

[16] Grinnell GB. Blackfoot Lodge Tails. The Story of a Prairie People. Lincoln: University of Nebraska Press; 2003

[17] Huffman MA. Animals as a Source of Medicinal Wisdom in Indigenous Societies. In: Bekoff M, ed. Encyclopedia of Human-Animal Relationships Vol. 2. CT: Greenwood Publishing Group; 2007: 434-441

[18] Pierotti R. Indigenous Knowledge, Ecology and Evolutionary Biology. New York: Routledge Taylor \& Francis Group; 2011

[19] Mailhot J. Traditional Ecological Knowledge: The Diversity of Knowledge Systems and their Study. Montreal: Great Whale Assessment 4. Great Whale Review; 1993

[20] Mezcua MÁ, Revuelta RL, Sánchez de Lollano PJ. The origins of zoopharmacognosy: How humans learned about self-medication from animals. Int J App Res 2019; 5: 73-79

[21] Huffman MA. Current evidence for self-medication in primates: a multidisciplinary perspective. Yrbk Phys Anthro 1997; 40: 171-200

[22] Forbey J, Harvey A, Huffman MA, Provenza F, Sullivan R, Tasdemir D. Exploitation of secondary metabolites by animals: A behavioral response to homeostatic challenges. Integr Comp Biol 2009; 49: 314-328

[23] Gradé JT, Taubutt JRS, Damme PV. Four footed pharmacists: Indications of self-medicating livestock in Karamoja, Uganda. Econ Bot 2009; 63: 29-42

[24] Mukherjee JR, Chelladurai V, Ronald J, Rawat GS, Mani P, Huffman MA. Do Animals eat what we do? Observations on Medicinal Plants used by Humans and Animals of Mudanthurai Range, Tamil Nadu. In: Kala CP, ed. Medicinal Plants and Sustainable Development. New York: Nova Science Publications; 2011: 179-195

[25] Costa-Neto EM. Zoopharmacognosy, the self-medication behavior of animals. Interface (Botucatu) 2012; 1: 61-72

[26] Villalba J], Miller J, Ungar ED, Landau SY, Glendinning J. Ruminant selfmedication against gastrointestinal nematodes: evidence, mechanisms, and origins. Parasites 2014; 21: 31

[27] Abbott J. Self-medication in insects: current evidence and future perspectives. Ecol Entomol 2014; 39: 273-280

[28] Rodriguez E, Wrangham R. Zoopharmacognosy: The use of medicinal plants by animals. Phytochemical Potential of Tropical Plants 1993; 27: 89-105

[29] Richter CP. Total self regulatory functions in animals and human beings. The Harvey Lectures 1943; 38: 63-103

[30] Hart BL. Behavioural defences in animals against pathogens and parasites: parallels with the pillars of medicine in humans. Philos Trans R Soc Lond B 2011; 366: 3406-3417

[31] Huffman MA. Self-Medication: Passive Prevention and Active Treatment. In: Choe JC, ed. Encyclopedia of Animal Behavior, (2nd ed.). Vol. 2. New York: Elsevier Academic Press; 2019: 696-702

[32] Huffman MA, Seifu M. Observations on the illness and consumption of a possibly medicinal plant Vernonia amygdalina by a wild chimpanzee in the Mahale Mountains, Tanzania. Primates 1989; 30: 51-63

[33] Huffman MA, Gotoh S, Izutsu D, Koshimizu K, Kalunde MS. Further observations on the use of the medicinal plant, Vernonia amygdalina (Del) by a wild chimpanzee, its possible effect on parasite load, and its phytochemistry. Afr Stud Monogr 1993; 14: 227-240

[34] Huffman MA, Koshimizu K, Ohigashi H. Ethnobotany and Zoopharmacognosy of Vernonia amygdalina, a Medicinal Plant used by Humans and Chimpanzees. In: Caligari PDS, Hind DJN, eds. Compositae: Biology \& Utilization Vol. 2. Kew: The Royal Botanical Gardens; 1996: 351-360

[35] Erasto P, Grierson DS, Afolayan AJ. Bioactive sesquiterpene lactones from the leaves of Vernonia amygdalina. J Ethnopharm 2006; 106: 117-120
[36] Yeap SK, Ho WY, Beh BK, Liang WS, Ky H, Hadi A, Yousr N, Alitheen NB. Vernonia amygdalina, an ethnoveterinary and ethnomedical used green vegetable with multiple bioactivities. J Med Plants Res 2010; 4: 27872812

[37] Ohigashi H, Huffman MA, Izutsu D, Koshimizu K, Kawanaka M, Sugiyama H, Kirby GC, Warhurst DC, Allen D, Wright CW, Phillipson JD, TimmonDavid P, Delmas F, Elias R, Balansard G. Toward the chemical ecology of medicinal plant use in chimpanzees: The case of Vernonia amygdalina, a plant used by wild chimpanzees possibly for parasite-related diseases. J Chem Ecol 1994; 20: 541-553

[38] Adedapo AA, Ostesile AT, Soetan KO. Assessment of the anthelmintic efficacy of an aqueous crude extract of Vernonia amygdalina. Pharm Biol 2007; 45: 564-568

[39] Egharevba C, Osayemwenre E, Imieje V, Ahomafor J, Akunyuli C, UduCosi AA, Theophilus O, James O, Ali I, Falodun A. Significance of bitter leaf (Vernonia amygdalina) in tropical diseases and beyond: A review. MCCE 2014; 3: 120

[40] Oyeyemi IT, Akinlabi AA, Adewumi A, Aleshinloye AO, Oyeyemi OT. Vernonia amygdalina: A folkloric herb with anthelminthic properties. BeniSuef University Journal of Basic and Applied Sciences 2018; 7: 43-49

[41] Huffman MA, Ohigashi H, Kawanaka M, Page JE, Kirby GC, Gasquet M, Murakami A, Koshimizu K. African Great Ape Self-Medication: A new Paradigm for Treating Parasite Disease with Natural Medicines? In: Ebizuka Y, ed. Towards Natural Medicine Research in the 21st Century. Amsterdam: Elsevier Science B.V.; 1998: 113-123

[42] Koshimizu K, Ohigashi H, Huffman MA, Nishida T, Takasaki H. Physiological activities and the active constituents of potentially medicinal plants used by wild chimpanzees of the Mahale Mountains, Tanzania. Int J Primatol 1993; 14: 345-356

[43] Krief S, Hladik CM, Haxaire C. Ethnomedicinal and bioactive properties of plants ingested by wild chimpanzees in Uganda. J Ethnopharm 2005; 101: $1-15$

[44] Obbo CJD, Makanga B, Mulholland DA, Coombes PH, Brun R. 2013. Antiprotozoal activity of Khaya anthotheca, (Welv.) C.D.C. a plant used by chimpanzees for self-medication. J Ethnopharm 2013; 147: 220-223

[45] Domínguez-Martín EM, Tavares J, Rijo P, Diaz-Lanza AM. Zoopharmacognosy: A way to discover new cancer treatments. Biomolecules 2020; 10: 817

[46] Huffman MA. Self-medicative behavior in the African Great Apes: An evolutionary perspective into the origins of human traditional medicine. Bioscience 2001; 51: 651-661

[47] Saar M. Ethnomycological data from Siberia and North-East Asia on the effect of Amanita muscaria. J Ethnopharm 1991; 31: 157-173

[48] Hobbs C. Medicinal Mushrooms. An Exploration of Tradition, Healing \& Culture. Summertown, TN: Botanica Press; 1986

[49] Ott J. Hallucinogenic Plants of North America. Berkeley, CA: Wingbow Press; 1976

[50] Hallucinogenic Mushrooms. Accessed June 1, 2021 at: https://faculty. washington.edu/chudler/mush.html

[51] Bellemain E, Zedrosser A, Manel S, Lisette P, Waits LP, Taberlet P, Swenson JE. The dilemma of female mate selection in the brown bear, a species with sexually selected infanticide. Proc R Soc B 2006; 273: 283-291

[52] Nautiyal H, Huffman MA. Interspecific feeding association between Central Himalayan langurs (Semnopithecus schistaceus) and Himalayan black bears (Ursus thibetanus) in a temperate forest of the Western Indian Himalayas. Mammal Study 2018; 43: 55-60

[53] Penteriani V, Zarzo-Arias A, del Mar Delgado M, Dalerum F, Gurarie E, Torre PP, Sánchez Corominas T, Vázquez VM, Vázquez García P, Ordiz A. Female brown bears use areas with infanticide risk in a spatially confined population. Ursus 2020; 31e2: 1-9

[54] Shi X, Wang C, Simon JE, Reichert W, Wu Q. Repellency of novel catnip oils against the bed bug (Hemiptera: Cimicidae). J Med Entom 2020; 1-7 
[55] Uenoyama R, Miyazaki T, Hurst JL, Beynon R], Adachi M, Murooka T, Onoda I, Miyazawa Y, Katayama R, Yamashita T, Kaneko S, Nishikawa T, Miyazaki M. The characteristic response of domestic cats to plant iridoids allows them to gain chemical defense against mosquitoes. Sci Adv 2021; 7: eabd9135

[56] Useful Tropical Plants. Accessed October 1, 2021 at: https://tropical. theferns.info/

[57] Chevallier A. The Encyclopedia of Medicinal Plants. London: Dorling Kindersley; 1996

[58] Wabe NT. Chemistry, pharmacology, and toxicology of khat (Catha edulis forsk): a review. Addict Health 2011; 3: 137-149

[59] Lallanilla M. Why the Herbal Stimulant 'Khat' was Banned. Live Science; 2013. Accessed March 1, 2021 at: https://www.livescience.com/37948what-is-khat-cathinone.html

[60] Drug Enforcement Administration (DEA). Drugs of Abuse. A DEA Resource Guide 2017 EDITION. Accessed March 1, 2021 at: https://www. dea.gov/sites/default/files/drug_of_abuse.pdf

[61] Institute of Medicine. Caffeine for the Sustainment of Mental Task Performance: Formulations for Military Operations. Washington, DC: The National Academies Press; 2001. doi:10.17226/10219

[62] Plotkin M]. Medicine Quest: In search of Nature's Healing Secrets. New York: Vikings Press; 2000

[63] Smith RFA. History of coffee. In: Clifford MN, Willson KC eds. Coffee: Botany, Biochemistry and Production of Beans and Beverage. London: Croom Helm; 1985: 1-12

[64] Anthony F, Combes MC, Astorga C, Bertrand B, Graziosi G, Lashermes P. The origin of cultivated Coffea arabica L. varieties revealed by AFLP and SSR markers. Theor Appl Genet 2002; 104: 894-900

[65] Outuga DBA. Chemical composition and potential commercial use of kola nut medicinal properties in the diet of gorillas Cola nitida, Vent. (Schott \& Erndlicher). Ghana J Agri Sci 1975; 8: 121-125

[66] Cousins D, Huffman MA. Medicinal properties in the diet of gorillasan ethnopharmacological evaluation. Afr Stud Monogr 2002; 23: 65-89

[67] Huffman MA, Sun BH, Li JH. Medicinal Properties in the Diet of Tibetan Macaques at Mt. Huangshan-A Case for Self-Medication? In: Li JH, Sun L, Kappeler P, eds. The Behavioral Ecology of the Tibetan Macaque. Cham: Springer Intl. Publ. Ag. 2020; 223-248

[68] Li C, Li Q, Mei Q, Lu T. Pharmacological effects and pharmacokinetic properties of icariin, the major bioactive component in Harba Epimedii. Life Sci 2015; 126: 57-68

[69] Wang L, Li Y, Guo Y, Ma R, Fu M, Niu J, Gao S, Zhang D. Herba epimedii: An ancient chinese herbal medicine in the prevention and treatment of osteoporosis. Curr Pharm Des 2016; 22: 328,

[70] Ma H, He X, Yang Y, Li M, Hao D, Jia Z. The genus Epimedium, an ethnopharmacolgical and phytochemical review. J. Ethnopharm 2011; 143: 519-541

[71] Frohne D, Pfänder JA. Colour atlas of poisonous plants. Portland: Timber Press; 1984

[72] Pan Y, Wang FM, Quang LQ, Zhang DM, Kong LD. Icariin attenuates chronic mild stress-induced dysregulation of the LHPA stress circuit in rats. Psychoneuroendocrinology 2010; 35: 272-283

[73] Wu J, Du J, Xu C, Le J, Xu Y, Liu B, Dong J. Icariin attenuates social defeatinduced down regulation of glucocorticoid receptor in mice. Pharmacol Biochem Behav 2011; 98: 273-278

[74] Gong M], Han B, Wang SM, Liang SW. Icariin reverses corticosterone-induced depression-like behavior, decrease in hippocampal brain-derived neurotrophic factor (BDNF) and metabolic network disturbances revealed by NMR-based metabonomics in rats. J Pharm Biomed 2016; 123: $63-73$

[75] Ma A, Qi S, Xu D, Xiaochun X, Daloze P, Chen H. Baohuoside-1, a novel immunosuppressive molecule, inhibits lymphocyte activation in vitro and in vivo. Transplantation 2004; 78(6): 831-838
[76] Blondich AS, Josline DJ. Coca, the history and medicinal significance of an ancient Andean Tradition. Emerg Med Int 2016; 4048764

[77] Politi M, Saudedo RG, Rumlerova T, Marcus O, Torres R], Mabit J. Medicinal plants diet as emerging complementary therapy from the Amazonian tradition. Data from Centro Takiwasi, a Peruvian therapeutic community. J Med Herbs Ethnomed 2019; 5: 23-28

[78] Boghdadi MS, Henning RJ. Cocaine: Pathophysiology and clinical toxicology. Heart Lung 1997; 26: 466-483

[79] Native Languages of the Americas website 1998-2015. Native American Osha (Bear Root) Mythology. Accessed March 3, 2021 at: http://www. native-languages.org

[80] Hartwell JL. Plants used against cancer. A survey. Lloydia 1971; 134 204-255

[81] Moore M. Medicinal plants of the Mountain West. Santa Fe: Museum of New Mexico Press; 1979

[82] Camazine S, Bye RA. A study of the medical ethnobotany of the Zuni Indians of New Mexico. J Ethnopharm 1980; 2: 365-388

[83] Bye RA. Medicinal plants of the Sierra Madre: comparative study of Tarahumara and Mexican market plants. Econ Bot 1986; 40: 103-124

[84] Terrell B, Fennell A. Oshá (bear root) Ligusticum porteri var. porteri Coult. \& Rose. Native Plants J 2009; 10: 110-118

[85] Turi C, Murch S]. The genus Ligusticum in North America: An ethnobotanical review with special emphasis upon species commercially known as 'Osha'. HerbalGram 2010; 89: 40-51

[86] Panda AK, Swain KC. Traditional uses and medicinal potential of Cordyceps sinensis in Sikkim. J Ayurveda Integr Med 2011; 2: 9-13

[87] Liu Y, Wang J, Wang W, Zhang H, Zhang X, Han C. The chemical constituents and pharmacological actions of Cordyceps sinensis. Evidence-Based Complementary Altern Med 2015; 2015: 575063

[88] Kokwaro JO. Medicinal Plants of East Africa. Nairobi: Kenya Literature Bureau; 1993

[89] Togola A, Diallo D, Dembélé S, Barsett H, Paulsen BS. Ethnopharmacological survey of different uses of seven medicinal plants from Mali, (west Africa) in the regions Doila, Kolokani and Siby. J Ethnobio Ethnomed 2005; $1: 7$

[90] Tira-Picos V, Nogueira MF, Adebayo A. Comparative analysis of leaf essential oil constituents of Piliostigma thonningii and Piliostigma reticulatum. Int J Green Pharm 2010; 4: 67-70

[91] Etsuyankpa MB, Ndamitso MM, Suleman MAT, Tijani JO, Idris S, Shaba EY, Mohammed A. The antibacterial activity and some trace elemental compositions of the extracts of Piliostigma thonningii, a widely used ethnomedicinal tree in Minna, Nigeria. Afr J Microbiol Res 2013; 1: 17-22

[92] Greene AM, Panyadee P, Inta A, Huffman MA. Asian elephant self-medication as a source of ethnoveterinary knowledge among Karen mahouts in northern Thailand. J Ethnopharm 2020; 259, e112823.

[93] Chaudhary SP, Singh AK, Ram B. A review of shilajatu based on samhitha and nighantus. World J Pharm Sci 2016; 4: 420-426

[94] Acharya SB, Frotan MH, Goel RK, Tripathi SK, Das PK. Pharmacological actions of Shilajit. Indian J Exp Biol 1988; 26: 775-777

[95] Chaudhary SP, Singh AK, Dwivedi KN. Medicinal properties of Shilajit A review. Indian 」 Agri. Allied Sci 2016; 2: 104-105

[96] Mittal P, Kaushik D, Gupta V, Bansal P, Khokra S. Therapeutic Potentials of "Shilajit Rasayana"-A Review. Int J Clin Pharmaol Res 2009; 1: 47-49

[97] Carrasco-Gallardo C, Guzman L, Maccioni RB. Shilajit: A natural phytocomplex with potential procognitive activity. Int J Alzheimer's Disease 2012; 2012: 674142

[98] Pope HG. Tabernanthe iboga, an African narcotic plant of social importance. Econ Bot 1969; 23: 174-184

[99] Goutarel R. Pharmacodynamics and therapeutic applications of iboga and ibogaine. In: De Rienzo R, Beal D, eds. The Ibogaine Story. New York: Autonomedia; 1997: 229-243 
[100] Landrin A. Étude botanique, pharmacologue, et chimique (Tabernanthe iboga). B Sci Pharmacol 1905; 11: 319

[101] Phisalix MC. Action physciologique de l'ibogaine. Contes Rendu Societé Biologue 1901; 53: 1077

[102] Chhabra SC, Mahunnah RLA, Mshiu EN. Plants used in traditional medicine in Eastern Tanzania. II Angiosperms (Capparidaceae to Ebenaceae). J Ethnopharm 1989; 25: 339-359

[103] Hilonga S, Otieno JN, Ghorbani A, Pereus D, Kocyan A, deBoer H. Trade of wild-harvested medicinal plant species in local markets of Tanzania and its implications for conservation. S Afr J Bot 2019; 122: 214-224

[104] Iwu MM. Handbook of African Medicinal Plants. London: CRC Press; 1993

[105] Fyhrquist P, Hiltunen R, Julkunen-Tiitto R. Antimicrobial ellagitanninrich extracts and ellagitannins in Terminalia kaiserana and Terminalia sambesiaca, two African medicinal plants. (Conference abstract). Planta Med 2013; 79: PE14. doi:10.1055/s-0033-1352033

[106] Huffman MA, Page JE, Sukhdeo MVK, Gotoh S, Kalunde MS, Chandrasiri T, Towers GHN. Leaf-swallowing by chimpanzees, a behavioral adaptation for the control of strongyle nematode infections. Int J Primatol 1996; 17: 475-503

[107] Huffman MA, Caton JM. Self-induced increase of gut motility and the control of parasitic infections in wild chimpanzees. Int J Primatol 2001; 22: 329-346

[108] Adinortey MB, Galyuon IK, Asamoah NO. Trema orientalis Linn. Blume: A potential for prospecting for drugs for various uses. Pharmacog Rev 2013; 3: 67-72

[109] Kendal RL. Social Learning and Culture in Nonhuman Organisms. In: Wright JD, ed. International Encyclopedia of the Social \& Behavioral Sciences. 2nd Edition, Vol. 22. Oxford: Elsevier; 2015: 401-408

[110] Ingraham C. How Animals heal Themselves. Herefordshire: Orphans Press; 2014

[111] Ingraham C. Animal Self-Medication. How Animals heal Themselves using Essential Oils, Herbs and Minerals. Leighterton: Ingraham Trading Ltd.; 2018 